\title{
P. MAVRICIJ PÖHM - GLASBENI MIGRANT? PRISPEVEK K POZNAVANJU ŽIVLJENJA IN DELA FRANČIŠKANSKEGA GLASBENIKA NA SLOVENSKEM V DRUGI POLOVICI 18. STOLETJA
}

\author{
RADOVAN ŠKRJANC \\ Znanstvenoraziskovalni center SAZU
}

\begin{abstract}
Izvleček: Prispevek pomembno dopolnjuje dosedanje védenje o življenju in delu frančiškanskega glasbenika p. Mavricija Pöhma (1745-1803) po njegovem vstopu $v$ red $v$ Kamniku že avgusta 1763. Nova spoznanja v zvezi s tem razkrivajo točni datum in ime kraja Pöhmovega rojstva na Češkem, njegovo krstno ime in to, da je večino svojega življenja prebil v samostanih na Slovenskem (v Kamniku, Ljubljani in Novem mestu). Nepojasnjeni v Pöhmovem življenju ostajata le dve krajši obdobji po njegovem prihodu v Kamnik (1764-1767 in 1771-1774). Zato je dosedanji »status" p. Pöhma kot glasbenega migranta in osebe, ki naj bi zaradi svojih vezi z rodno Češko in selitev iz enega v drugi samostan odločilno prispevala $k$ dospetju takrat sodobne glasbe srednjeevropskih skladateljev iz tujine $k$ nam, vprašljiv. Temu pritrjujejo tudi nekateri (že objavljeni) izsledki raziskave porekla t. $i$. »Pöhmovih muzikalij«v Novem mestu, ki so večinoma domačega (kranjskega) izvora.
\end{abstract}

Ključne besede: p. Mavricij Pöhm, frančiškanski glasbeniki, glasba druge polovice 18. stoletja

\begin{abstract}
The paper offers significant new information that supplements what has been known to date about the life and work of Mauritius Pöhm (1745-1803), a Franciscan friar and musician, after his entry into the order in Kamnik in August 1763. These new findings reveal the accurate date of his birth and the name of his birthplace in Bohemia, his Christian name, and the fact that he spent most of his life in monasteries in Slovenian territory (in Kamnik, Ljubljana, and Novo mesto). Only two brief periods in Pöhm's life remain unexplained, both following his arrival in Kamnik (1764-1767 and 1771-1774). For this reason, the prior glorification of Pöhm as a musician who decisively influenced the arrival of Central European music of that era in Slovenia from abroad (due to his ties with his native Bohemia and the migrant character of his life as a Franciscan monk), has become questionable. This is also shown by the (already published) findings of a study of the origins of the Pöhm music collection in Novo mesto, which reveals that most of its manuscripts are of domestic (Carniolian) provenance.
\end{abstract}

Keywords: P. Mauritius Pöhm, Franciscan musicians, music of the second half of the 18th century

Vse od sredine 60. let prejšnjega stoletja, ko se je v frančiškanskem samostanu Novo mesto našla pomembna zbirka muzikalij iz 18 . stoletja, velja domneva, ${ }^{1}$ da je bil za nastanek

1 Več o tem Höfler, »Glasbenozgodovinske najdbe XVIII. in XIX. stoletja v Novem mestu«, 135. 
tega razmeroma obsežnega repertoarja posebno zaslužen p. Mavricij Pöhm (tudi Böhm) ${ }^{2}$ - frančiškan in organist, rojen na Češkem leta 1745, ki naj bi v Novo mesto prišel okoli leta 1774, ko je prevzel dolžnosti učitelja na tamkajšnji gimnaziji. Vzrok za to domnevo so zapisi Pöhmovega imena na številnih notah v Novem mestu iz druge polovice 18 . stoletja, ki govorijo o Pöhmovi »osebni rabi« teh not pri delu v novomeškem samostanu (»Ad Simplicem Usum P. Mauritii Pöhm OMR«). Pöhmovo češko poreklo naj bi že načeloma pojasnjevalo »slogovno orientacijo omenjenega repertoarja, ki ga zaznamujejo zlasti znani češki in drugi ustvarjalci iz Srednje Evrope v času klasicizma« ${ }^{3}$ (Češka in njeni številni glasbeniki, ki so delovali in potovali po vsej Evropi, so bili namreč eden vodilnih dejavnikov v razvoju glasbe tega obdobja); seveda pa ponuja tudi možnost, da je obstoj vsaj nekaterih muzikalij čeških avtorjev v Novem mestu mogoče neposredneje razložiti s stiki, ki jih je Pöhm imel morda s svojim rojstnim okoljem še po prihodu v Novo mesto. Vsaj nekaj takšnih skladb bi Pöhm lahko prinesel s Češkega že tedaj, ko je prišel v naše kraje.

Vse to in nedavno zapisana trditev Petra Kinderića, da je Pöhm nekaj časa prebival tudi na Hrvaškem (v samostanu v Samoboru, ki je takrat sodil v isto redovno provinco kot novomeški samostan), ${ }^{4}$ je Pöhmovo ime postavilo v ospredje raziskovanja glasbenih migracij na Slovenskem v obdobju 18. stoletja. Preučitev Pöhmovega mesta v tem dogajanju je obsegala dve področji raziskav. ${ }^{5}$ Prvo sta bili papirološka in grafološka raziskava glasbenega repertoarja pri novomeških frančiškanih iz tega obdobja z namenom, ugotoviti točni delež muzikalij, ki jih je mogoče neposredno povezovati s p. Pöhmom, ter izvor in datum njihovega nastanka. Metodološko sta raziskavi temeljili na analizi papirja rokopisov s pomočjo vodnih znakov in na ugotavljanju, katera od pisav v njih je Pöhmova. Kljub še vedno nekaterim nerazrešenim vprašanjem, predvsem glede različnih oblik Pöhmovega rokopisa, sta raziskavi ugotovili nekaj nedvoumnih spoznanj. Na eni strani sta potrdili domnevo o pomembnejši vlogi p. Pöhma pri nastajanju glasbenega repertoarja v Novem mestu v zadnjih desetletjih 18. stoletja, saj je skoraj tretjino od omenjenih rokopisov, ki so skoraj zanesljivo nastali pred Pöhmovo smrtjo 1803, mogoče neposredno povezovati z njegovo navzočnostjo v novomeškem samostanu ali kje drugje na območju tedanje slovensko-hrvaške frančiškanske province Sv. Križa. Po drugi strani pa je med pregledanimi »Pöhmovimi muzikalijami« v Novem zares le nekaj takšnih, za katere lahko utemeljeno sklepamo, da so na območje te province prišli od drugod (in sicer z Dunaja in Češke, morda tudi z Moravske). Večina rokopisov v Novem mestu, ki vsebujejo različne »pisne sledi« p. Pöhma, je namreč izdelana na domačem (kranjskem) papirju iz druge polovice 18. stoletja ali pa na papirju iz sosednjih dežel (zlasti Goriške, Koroške in Štajerske), ki

2 V več v nadaljevanju navedenih virih je Pöhmov priimek nedvoumno zapisan tudi kot Böhm, vendar pa je v Pöhmovih lastnih zapisih priimek zmeraj zapisan s črko P, torej kot Pöhm.

3 Höfler, »Glasbenozgodovinske najdbe XVIII. in XIX. stoletja v Novem mestu «, 136; prim. tudi Höfler, Tokovi glasbene kulture na Slovenskem, 112-113.

4 Kinderić, Franjevci uz orgulje, 102-103.

5 Raziskavi sta bili del raziskovalnega projekta »Music Migrations in the Early Modern Age: the Meeting of the European East, West and South« v okviru programa HERA. 
je bil na Kranjskem razmeroma zelo razširjen že v šestdesetih letih in nato med sedemdesetimi in devetdesetimi leti 18. stoletja. ${ }^{6}$

Zadnje torej močneje nasprotuje domnevi, da je Pöhm rokopise, ki jih lahko prištevamo med njegovo »osebno zapuščino, « v večjem številu prinesel k nam iz tujine (več o tem v nadaljevanju prispevka), obenem pa daje raziskavi njegovega življenja - drugemu področju raziskovanja delovanja p. Pöhma - dodatni pomen: Kolikor manj so Pöhmu pripisane zasluge za prispetje glasbe aktualnih čeških in drugih srednjeevropskih ustvarjalcev k nam v zadnjih desetletjih 18. stoletja prepoznavne neposredno v ohranjenem gradivu iz tega obdobja, toliko bolj je njegova življenjska pot - kot življenje lastnika in celo avtorja rokopisov s takšno glasbo, zelo verjetno izdelanih pri nas - zanimiva še z vidika »migracije glasbenih idej,« h kateri je Pöhm svoj delež dodal vsaj kot slednik takrat sodobnih glasbenih nazorov.

\section{$* * *$}

Raziskava Pöhmovega življenja je preučila vire, ki osvetljujejo Pöhmov prihod v naše kraje ter njegovo življenje in delo pri nas. ${ }^{7}$ Razkrila je številna nova spoznanja, ki deloma le dopolnjujejo, deloma pa tudi spreminjajo preteklo védenje o Pöhmovem življenju, ki je obsegalo naslednje podatke: ${ }^{8}$ njegovo rojstvo nekje na Češkem okoli leta 1745; njegov vstop v frančiškanski red leta 1763, neznano kje; Pöhmovo bivanje v Samoboru leta 1769; Pöhmovo poučevanje na gimnaziji v Novem mestu med leti 1774 in 1786 ter vodenje te ustanove v letih 1784 in 1785; Pöhmovo šestnajstletno predstojništvo novomeškim frančiškanom do njegove smrti 9. aprila 1803; ter označitev Pöhma ob vpisu smrti kot »organista in odličnega glasbenika.« Sem lahko prištejemo še že omenjene zaznamke s Pöhmovim imenom na notah pri novomeških frančiškanih, na Hrvaškem ohranjeno skladbo Litaniae ex C Organo con Canto s pripisom avtorstva: »P: Mauritio Pöhm | Franciscano «, ${ }^{9}$ pa tudi skladbo Aria de Immaculata, ki je v Novem mestu in je zelo verjetno tudi Pöhmovo delo. ${ }^{10}$

Nova dognanja o življenju p. Pöhma, kot že rečeno, po eni strani pritrjujejo mnenju o p. Pöhmu kot glasbeniku-migrantu s Češkega, katerega selitve iz samostana v samostan so bile posledica običajnih premestitev redovnikov v različne kraje delovanja njihovega reda. Po drugi strani pa ta spoznanja tudi omejujejo možnost, da je Pöhm večino rokopisov s takrat sodobno (tujo) glasbo v Novo mesto in na območje kranjskega dela province Sv. Križa prinesel od drugod. V to smer napeljujejo tudi izsledki raziskave izvora in datuma nastanka teh muzikalij.

Vseeno pa pri tem ostaja še nekaj nerazrešenih vprašanj. Pomembnejši dve sta med seboj morda povezani: prvo je vprašanje o provenienci »Pöhmovih muzikalij«, ki vsebujejo

6 Podrobneje o tem Škrjanc, »P. Mauritius Pöhm and his contribution to musical life in Novo mesto during the second half of the eighteenth century«, 233-244.

7 Za pomoč pri dostopu $\mathrm{k}$ virom in njihovem preučevanju se iskreno zahvaljujem dr. Jožetu Škofljancu.

8 Höflerjeva razprava izhaja iz dveh virov: »Nekrolog province Sv. Križa v NM za leta 1490-1896«, Vrhovec, Zgodovina Novega mesta, 1891.

9 HR-KLf C-3, RISM 500077902.

${ }^{10}$ SI-Nf Ms. mus. 114b, RISM 540000794. 
papir neznanega izvora ter papir beneškega, furlanskega in moravskega izvora; drugo je vprašanje o dveh obdobjih v Pöhmovem življenju po prihodu v naše kraje, za kateri ni znano, kje ju je prebil. Kot bo še pojasnjeno, gre za krajši vrzeli v sedanjem poznavanju Pöhmove življenjske poti po prihodu na Kranjsko; možno je, da je Pöhm ta čas, tako kot svoje otroštvo, prebil izven naših krajev.

Kljub temu se zaradi omenjenih novih dognanj o Pöhmovem življenju in izvoru muzikalij v njegovi zapuščini postavlja še tretje bolj temeljno vprašanje, ki tematizira pomen »migrantstva« pri p. Pöhmu kot glasbeniku nasploh. Gre za vprašanje dejanskega vpliva njegovega češkega porekla na eni in selitev iz samostana $\mathrm{v}$ samostan na drugi strani na vsebino Pöhmovega glasbenega dela. Dokumenti iz 18. in z začetka 19. stoletja v ljubljanskem in novomeškem frančiškanskem samostanu namreč kažejo, da je p. Mavricij Pöhm (s krstnima imenoma »Josephus Antonius«) prišel na Slovensko, natančneje v kamniški noviciat, vsaj že leta 1763, torej že vsaj z osemnajstimi leti; da je nato pri nas preživel večino svojega življenja do smrti aprila 1803; da je bilo njegovo bivanje v hrvaškem Samoboru leta 1769 kvečjemu le kratkotrajno, saj je bil tega leta še vedno član ljubljanske družine frančiškanov, seznam redovnikov v samoborskem samostanu za leto 1769 pa Pöhma ne omenja. ${ }^{11}$ Kot že rečeno, ostajata nepojasnjeni le dve krajši razdobji v Pöhmovem življenju po prihodu v Kamnik: prvo je od avgusta 1764, ko je še enkrat omenjen med kamniškimi frančiškani, in jesenjo leta 1767, ko ga srečamo na seznamu frančiškanov v Ljubljani; podobno se avgusta 1771 sled za njim v dokumentih spet izgubi, ponovno pa njegovo ime najdemo na seznamu učiteljev v novomeški gimnaziji iz leta 1774.

Glavni viri za te podatke so:

(1) Tyrocinium seraphicum v Arhivu slovenske frančiškanske province Sv. Križa v Ljubljani (ASFP). ${ }^{12}$ Rokopis vsebuje podatke za leta med 1660 in 1826 . V prvem delu podaja imena vseh novicev v nekdanji slovensko-hrvaški provinci Sv. Križa za to obdobje, nekatere osnovne podatke o njih in datum začetka njihove enoletne preizkušnje redovnega življenja. V drugem delu navaja imena tistih, ki so to preizkušnjo uspešno prestali in se zaobljubili frančiškanskemu redu. Tu je tudi podatek, da je bil Pöhm rojen 24. aprila 1745 v čeških Pavlovicah, ni pa jasno, v katerih, saj je na Češkem kar trinajst krajev, ki nosijo to ime. ${ }^{13}$

${ }^{11}$ Seznam je del popisa vseh redovnikov v provinci Sv. Križa z dne 4. oktobra 1769 (»Tabula Familiarum Provinciæ S. Crucis Croatiæ Carinioliæ de anno 1769«) v Protokolu frančiškanskega samostana $v$ Ljubljani iz let 1765- 1785 (glej nadaljevanje prispevka). Tu je Mavricij Pöhm naveden med »patri in fratri študenti« v ljubljanskem samostanu (fol. 184) in edini kot organist, kar dodatno utrjuje možnost, da je bil Pöhm vsaj jeseni tega leta res v Ljubljani in ne v Samoborju.

${ }^{12}$ TYROCINIVM SERAPHICVM $\mid$ Seu $\mid$ Liber continens Nomina, Cognomina, aetatem, |qualitatem, et Patriam eorum [...] | in Prouincia Bosnae | Croatiae et Carnioliae ad probationis annum | admissi, eodemqe faeliciter absoluto Solemnem | Professionem iuxta Sacros Canones, Conc:Trid: | et Constitutionum Apostolicarum Decreta, | emiserunt, uel ante completum eundem proba= | tionis annum ob certas, et legitimas causas | ad propria Sunt remissi. | IN DVAS DIVISVS PARTES | Quarum prior nouiter indutorum, | Posterior uero Solemniter Professorum | Seriem continet.

${ }^{13}$ Ti kraji so: Moravecké Pavlovice (okraj Žd’ár nad Sázavou); Slezské Pavlovice (okraj Bruntál); Velké Pavlovice (okraj Břeclav); Pavlovice (okraj Benešov); Pavlovice u Kojetína (okraj Prostějov); Pavlovice u Přerova (okraj Přerov); Bohdalice-Pavlovice (okraj Vyškov); Pavlovice / Vlastějovice 


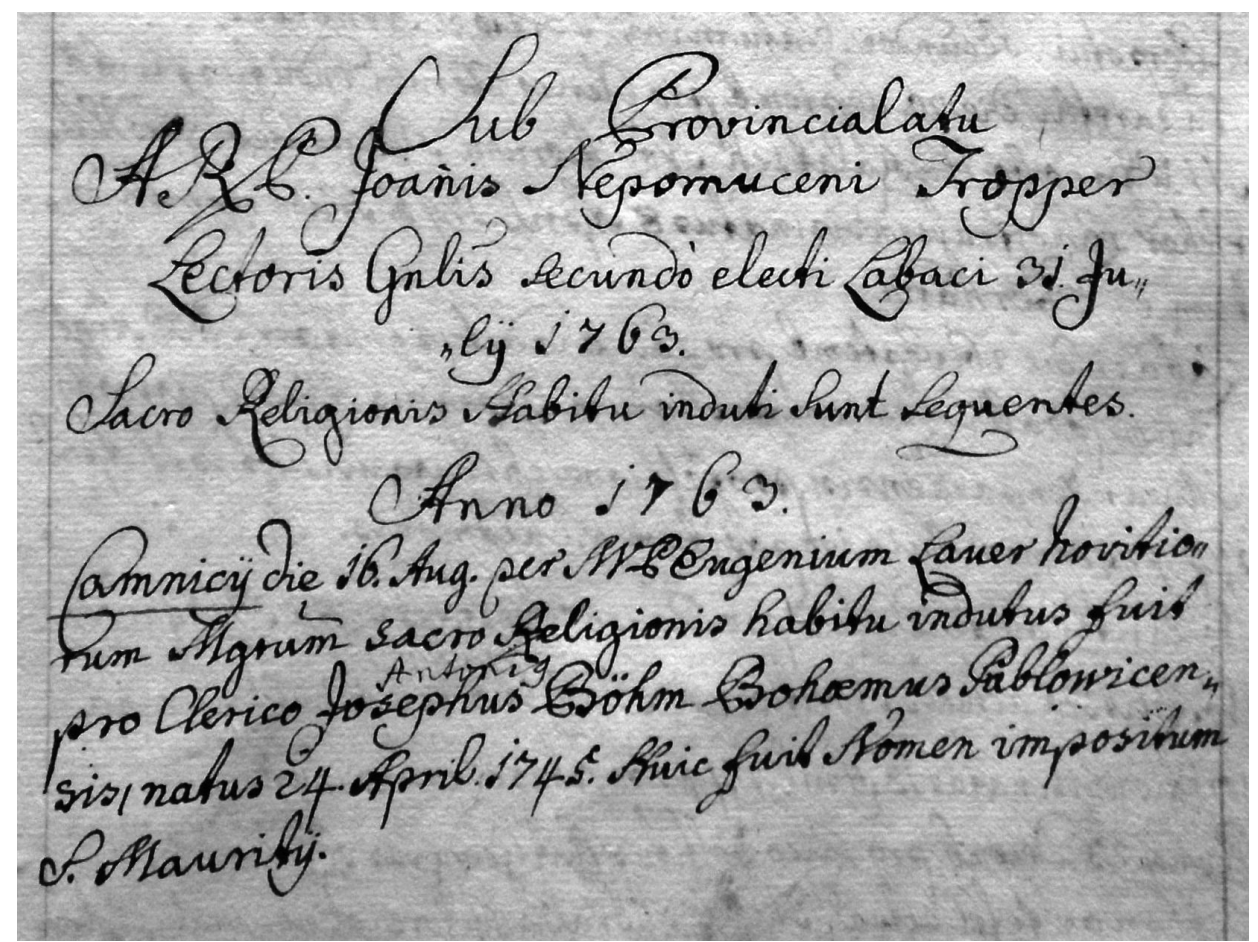

Slika 1: Zapis o Pöhmovem vstopu v kamniški noviciat dne 16. avgusta 1763 (Tyrocinium seraphicum)

(2) Seznami redovnikov province Sv. Križa, shranjeni v ASFP, kot sta npr. Catalogus Omnium Patrum ac Fratrum | Nostrce reformatae Provinciae |S. Crucis Croatice Carniolice etc. | descriptus | Anno | 1779 in Tempore | gubernante Provinciam | A. R. P. | Joanne Nepom. Tropper | Min. Prov. | a. 1764, ki potrjujeta čas Pöhmovega vstopa v noviciat dne 16. avgusta 1763 in njegov vstop v frančiškanski red leto pozneje, ko je provinco Sv. Križa drugič vodil provincial Johann Nepomuk Tropper (od 31. julija 1763 do 4. marca 1765). V zadnjem spisu, napisanem za leto 1764, je Pöhm omenjen kot »frater « v kamniški družini s pripisom »Cleric. Org.«, ki pove, da je bil takrat - s približno devetnajstimi leti torej - že dejaven kot organist. Tudi večina poznejših zapisov njegovega imena je nosi določilo »organist«. Enako je s p. Benom Majerjem (»Benno Mayr«), devet let starejšim frančiškanom s Tirolskega, ki je bil leta 1764 tako kot Pöhm v Kamniku samostanski organist, poleg tega pa še učitelj novicev v petju (»VP. Benno Maÿr Org. instruet Novitios in cantu $\ll){ }^{14}$

(okraj Kutná Hora); Pavlovice / Planá, tudi Pavlovice nad Mží (okraj Tachov); Pavlovice / Jestřebí (okraj Česká Lípa); Jimramovské Pavlovice (okraj Žd’ár nad Sázavou); Staré Pavlovice (okraj Liberec); Nové Pavlovice (okraj Liberec).

${ }^{14}$ Gl. Tempore gubernante Provinciam A. R. P. Joanne Nepom. Tropper, razdelek »Familia Conventus Camnicensis« (fol. 16). Drugo gradivo, ki je pri frančiškanih v Novem mestu in Ljubljani, o Benu Majerju pove še to, da se je rodil na Tirolskem dne 19. oktobra 1736 (bil je 
Med seznami frančiškanskih redovnikov province Sv. Križa iz 18. stoletja velja omeniti še Catalogus | Omnium Patrum, et Fratrum Provincice Croatice, Carniolice S. Crucis, ki za leta 1759, 1760 in 1761 navaja imena vseh redovnikov v tej provinci (za vsako leto približno 420), vendar ne tudi imena Jožefa Antonija Pöhma, ki je pozneje sprejel redovno ime p. Mavricij. Pač pa navajata seznama iz let 1760 in 1761 nekega Poncijana Pöhma (»Pontianus Pöhm«), »laičnega brata« v Karlovcu. ${ }^{15}$ Morda je bil prihod Mavricija Pöhma v slovensko-hrvaško frančiškansko provinco Sv. Križa povezan s to osebo.

Prihodi novicev iz bolj oddaljenih dežel, kot je bila Češka, so bili za provinco Sv. Križa takrat nekaj običajnega, saj so v omenjenih seznamih precej številni zapisi o prispetju mladih kandidatov za vstop v frančiškanski red še iz Bavarske, Tridenta in Madžarske, posebno veliko jih je prišlo s Tirolskega, nekaj pa tudi - tako kot najbrž Pöhm - s Češkega. Tudi noben drugi do sedaj preiskani dokument pri nas, ki se nanaša na obdobje pred avgustom 1763, ne omenja p. Pöhma.

(3) Pomembnejša vira za poznavanje Pöhmovega življenja, ki sta v ASFP, sta še Protokol frančiškanskega samostana v Ljubljani, napisan v letih od 1765 do 1785, ${ }^{16}$ in Protokol frančiškanske province Sv. Križa iz let od 1772 do $1784 .{ }^{17}$ Poleg različnih dekretov in drugih aktov, ki so urejali življenje redovnikov v ljubljanskem samostanu, so v prvem rokopisu še seznami redovnikov v tem samostanu, pa tudi seznami redovnikov, ki so opravljali pomembnejše zadolžitve v preostalih samostanih province Sv. Križa (tj. v petnajstih samostanih do leta 1783, ko se je provinca razdelila na hrvaški in »kranjski« del, v katerem je ostalo aktivnih še sedem samostanov). Najzgodnejši zapis Pöhmovega imena v tem rokopisu je iz oktobra 1767, in sicer v seznamu študentov teologije v Ljubljani. Tu je Pöhm zaveden še kot »frater«, že naslednje leto pa kot »častitljivi oče« (»V[enerabilis] $\mathrm{P}[$ ater $] \ll)$, vendar še vedno med »Patres et Fratres Studentes« frančiškanske družine v Ljubljani. Enako še v letih 1769 in 1770, ko je najverjetneje že sklenil triletni študij teologije, saj ga seznam ljubljanskih redovnikov iz avgusta 1771 ne omenja več med »patri in fratri študenti«, temveč kot enega od dveh organistov v samostanu (drugi organist je bil pater »Liborius Glögler $\left.{ }^{18}\right)$. Po tem datumu se sled za p. Pöhmom v teh dokumentih za približno tri leta izgubi.

»Doblacensis«), da je v frančiškanski red vstopil s krstnima imenoma Joannes Antonius avgusta 1754 v Kamniku, da je bil že leta 1759 organist v Ljubljani, tako še v letih 1760 in 1761, da je v Kamniku leta 1764 poučeval novice, leta 1769 pa brate laike, da je tu kot organist deloval vsaj še v letih 1772-1775 in leta 1781, v Karlovcu pa bil v letih 1776-1780 in po letu 1782 tudi vikar, ter da je umrl v Karlovcu 20. maja 1818.

${ }^{15}$ G1. Catalogus Omnium Patrum, et Fratrum Provincice Croatice, Carniolice S. Crucis, fol. 13 in 20. Spis je v ASFP. Nekrolog v Knjižnici frančiškanskega samostana v Novem mestu (glej nadaljevanje prispevka) pravi, da je bil Poncijan Pöhm po rodu Ljubljančan in da je umrl 16. novembra 1775 v Karloveu (fol. 336).

${ }^{16}$ Liber $[\ldots] \mid$ Literaru[...] | incl[ ...]. Navedeni zapis je na poškodovani platnici rokopisa, ki je brez naslovnice.

17 5. | Acta Capit. et | Epistolae Encyc. | 1772-1784. Navedeni zapis je na platnici rokopisa, ki je brez naslovnice.

${ }^{18}$ P. Liborija Glöglerja (1. februar 1747 - 16. december 1791) pregledano gradivo prvič omenja leta 1769 kot študenta v Brežicah, nato pa še v letih 1771, 1772 in 1779 kot organista v ljubljanskem 


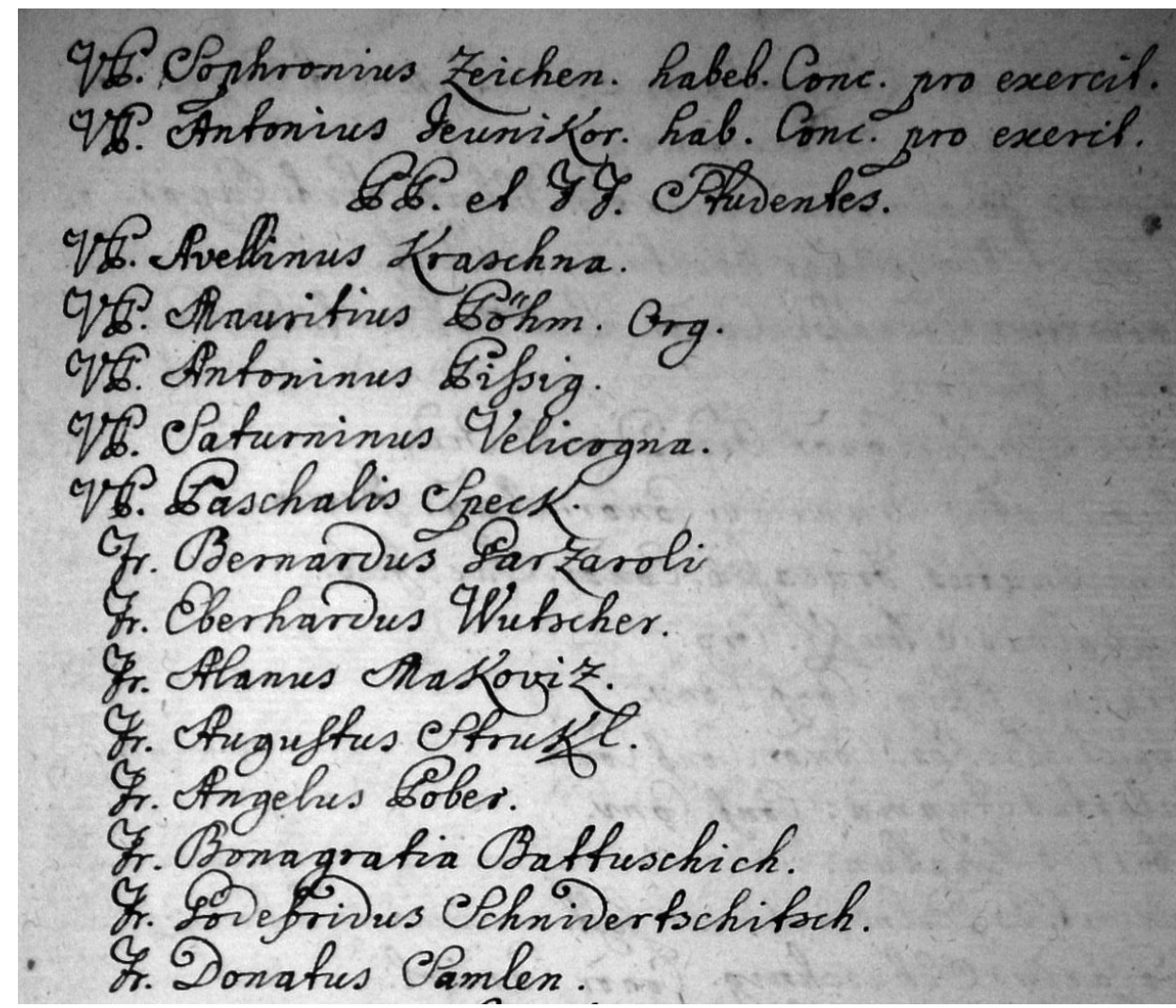

Slika 2: Vpis p. M. Pöhma v seznamu študentov teologije v Ljubljani z dne 4. oktobra 1769 (Protokol frančiškanskega samostana $v$ Ljubljani 1765-1785)

Ponovno se Pöhmovo ime pojavi v popisu učiteljev cesarsko-kraljeve gimnazije v Novem mestu iz leta 1774, tj. v popisu frančiškanov, ki so skrbeli za pouk na tej sicer državni ustanovi. Tega leta je bil Pöhm učitelj prvega (»parva«) in drugega (»principia«) razreda, že naslednje leto pa je prevzel pouk sintakse in gramatike v tretjem in četrtem razredu oz. $\mathrm{v}$ drugem in tretjem razredu, ${ }^{19} \mathrm{ki} \mathrm{ju}$ je poučeval še naslednja štiri leta, do leta 1780 , ko je

samostanu, leta 1783 pa kot organista v Novem mestu. V frančiškanski red je vstopil septembra 1765. V novomeškem nekrologu (glej nadaljevanje prispevka) izvemo, da je bil po rodu Avstrijec ter da je umrl v Samoborju.

${ }_{19}$ Pouk v novomeški gimnaziji so vse od njene ustanovitve leta 1746 do začetka 19. stoletja vodili trije učitelji iz vrst frančiškanov. Do leta 1777 je gimnazija imela šest razredov, ki so se imenovali »parva« (1. razred), »principia« (2. razred), »grammatica« (3. razred), »sintaxis« (4. razred), »poesis« (5. razred) in »rhetorica« (6. razred). Po letu 1777 je pouk do šolske reforme pod francosko oblastjo leta 1811 obsegal pet razredov: 1. razred ali »principia« (»infima grammatica cl.«), 2. razred ali »grammatica« (»media grammatica cl.«), 3. razred ali »syntaxis« (»suprema grammatica cl.«), 4. razred ali »rhetorica« (»secunda humaniorum cl.«) in 5. razred ali »poesis« (prima humaniorum cl.«). Vrhovec, Zgodovina Novega mesta, 270-276; gl. tudi 


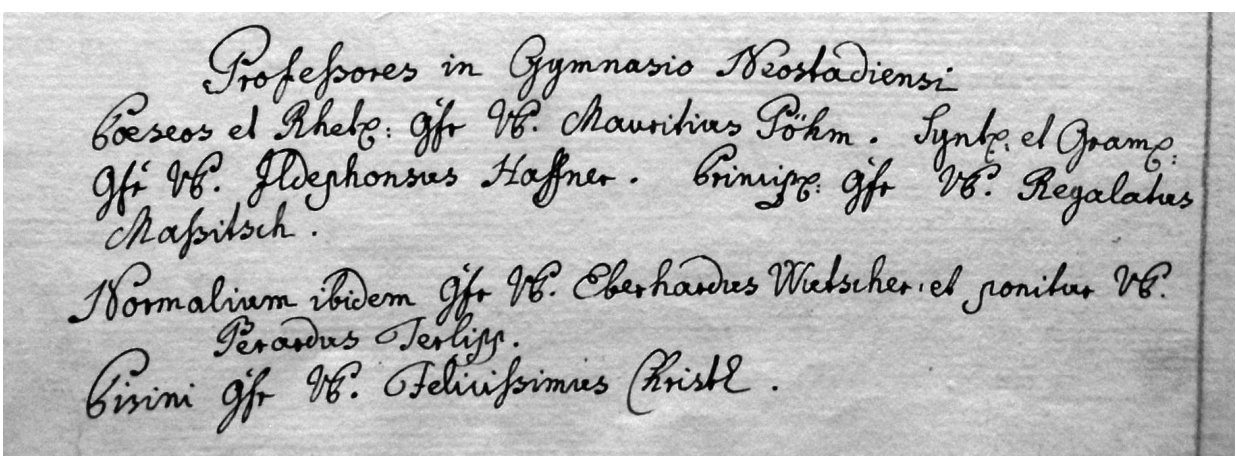

Slika 3: Zapis o Pöhmovem poučevanju poetike in retorike na gimnaziji v Novem mestu iz leta 1783 (Protokol frančiškanske province Sv. Križa 1772-1784)

začel učiti retoriko v četrtem in poetiko v petem razredu. Te podatke vsebujeta oba zadnje omenjena dokumenta. Iz njiju še izvemo, da Pöhm na gimnaziji v Novem mestu - kot je domneval že Höfler ${ }^{20}$ - res ni poučeval pred letom 1774, ali vsaj ne pred avgustom 1773.

(4) Trije glavni viri za preučevanje Pöhmovega življenja in dela v novomeškem samostanu in gimnaziji po začetku osemdesetih let 18. stoletja so: (1) PROTOCOLUM|complectens ea, | quce | Spectant ad Spiritualia, | ac Disciplinam internam, napisan za leta od 1782 do 1820; (2) PROTOCOLUM P: PROVINCIALIS | RERUM SPIRITUALIUM | CAESA: REGIO MANDATO INSTITUTUM. $\mid$ ANNO |M.D.C.C.LXXXI, ki razen nekaj poznejših dodatkov $\mathrm{v}$ resnici vsebuje prepise dekretov in drugih uradnih spisov iz let od 1788 do $1803 ;{ }^{21}$ (3) NECROLOGI: | UM. PROVINCIAE S. SRUCIS | Croatice - Carniolice tam unitce, quam se: | paratce, quondam Bosnce - Croatice, adjunc: | tis etiam Fratribus, qui per Sexennium in | Conventibus Styrice, et Carinthice decreto | Josephi II. Provinciace Carniolice unitis | obierunt. | Ab anno 1490. [...], ki vsebuje vpise smrti in krajše nekrologe redovnikom, umrlih v letih od 1490 do 1896 . Vsi trije viri so v Knjižnici frančiškanskega samostana v Novem mestu (FSANm).

V nekrologu p. Mavriciju Pöhmu je podatek o njegovem kar šestnajstletnem vodenju novomeških frančiškanov. Več podatkov o izvolitvi Pöhma za gvardijana novomeškega samostana in njegovem opravljanju te funkcije od januarja 1788 do smrti aprila 1803 pa

Furlan, »Zgodovina frančiškanskega samostana in cerkve v Novem mestu«, Dolenjske novice, 19. junij 1919.

${ }^{20}$ Höfler, »Glasbenozgodovinske najdbe XVIII. in XIX. stoletja v Novem mestu«, 136.

${ }^{21} \mathrm{~V}$ rokopisu sta še dva lističa; prvi nosi napis DECRETA | et $\mid$ ORDINATIONES | CAES: REGIAE. | 1788 - 1803 (letnici sta pozneje dodani s svinčnikom), drugi pa Decreta et Or $\mid$ dinationes $\mid$ Archi eppi Labac. | \& | Imperatoris | Josephi II. Rokopis torej le dopolnjuje prej omenjeni protokol v Novem mestu iz let 1782-1820, ki za leta med 1788 in 1803, ko je novomeški samostan vodil p. Pöhm, vsebuje le nekatere osnovne podatke v zvezi s samostanom (kot so letna finančna poročila, popisi redovnikov v njem ipd.). Preostali ohranjeni protokoli v ljubljanskem in novomeškem samostanu ne delijo omenjenih podatkov in prepisov dekretov in drugih spisov, ki so zadevali delovanje samostana, na dve knjigi. 
najdemo v obeh prej navedenih novomeških virih. Z njuno pomočjo je bilo mogoče tudi dokončno identificirati Pöhmov rokopis, saj so z njim napisani denimo vsi prepisi uredb in drugih uradnih spisov, ki so v novomeškem »provincialnem protokolu« iz let od 1788 do 1803, torej ravno iz časa, ko je Pöhm vodil novomeški samostan. Zanesljivo poznavanje Pöhmove pisave je seveda pomembno zlasti za ugotavljanje točnega obsega notnih rokopisov, ki jih je Pöhm uporabljal pri svojem delu.

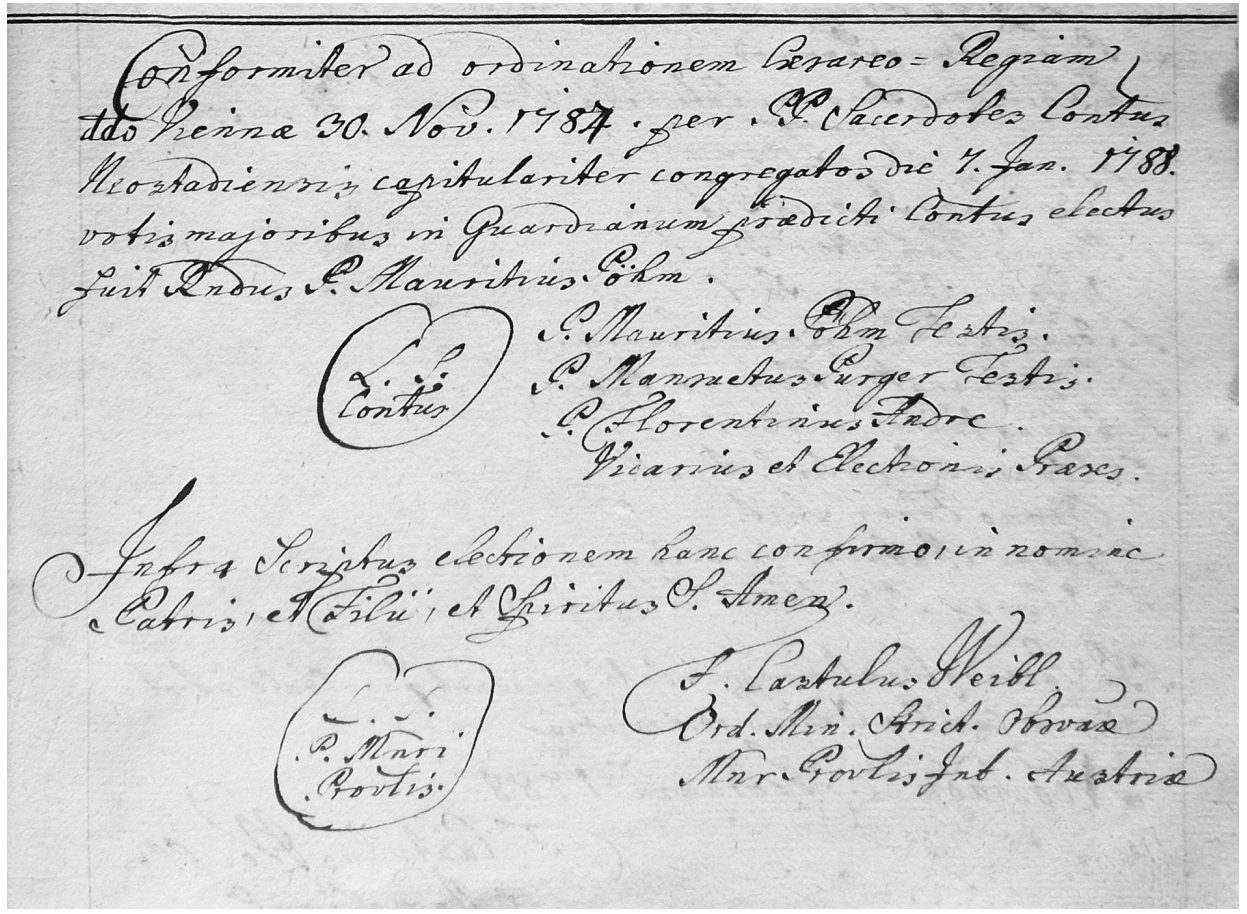

Slika 4: Zapis o izvolitvi p. M. Pöhma za gvardijana novomeškega samostana s konca leta 1787 (Protocolum za leta 1782-1820)

Nekaj primerov Pöhmove pisave je tudi v še neurejenem gradivu novomeške gimnazije iz 18. in 19. stoletja (večinoma gre za prepise učbenikov in drugih pedagoških spisov, ki se nahajajo v Knjižnici frančiškanskega samostana v Novem mestu). Eden takšnih primerov je dobre štiri strani obsegajoč spis Prolusio academica | in | Honoraria Studiosorum benemeritorum | Lectione dicta.

Iz protokola, napisanega za leta od 1782 do 1820, izvemo, da je postal Pöhm leta 1784 učitelj bratov laikov v samostanu ter prefekt gimnazije in direktor normalke v Novem mestu; šoli sta delovali $\mathrm{v}$ isti zgradbi nasproti samostana. Na mestu ravnatelja gimnazije je vztrajal le eno leto. Naslednji dve leti (1785 in 1786) je v njej ponovno poučeval retoriko in poetiko ter bil tudi katehet, leta 1802 pa je bil učitelj novicev v samostanu (»Novitiorum Mgr.«). 


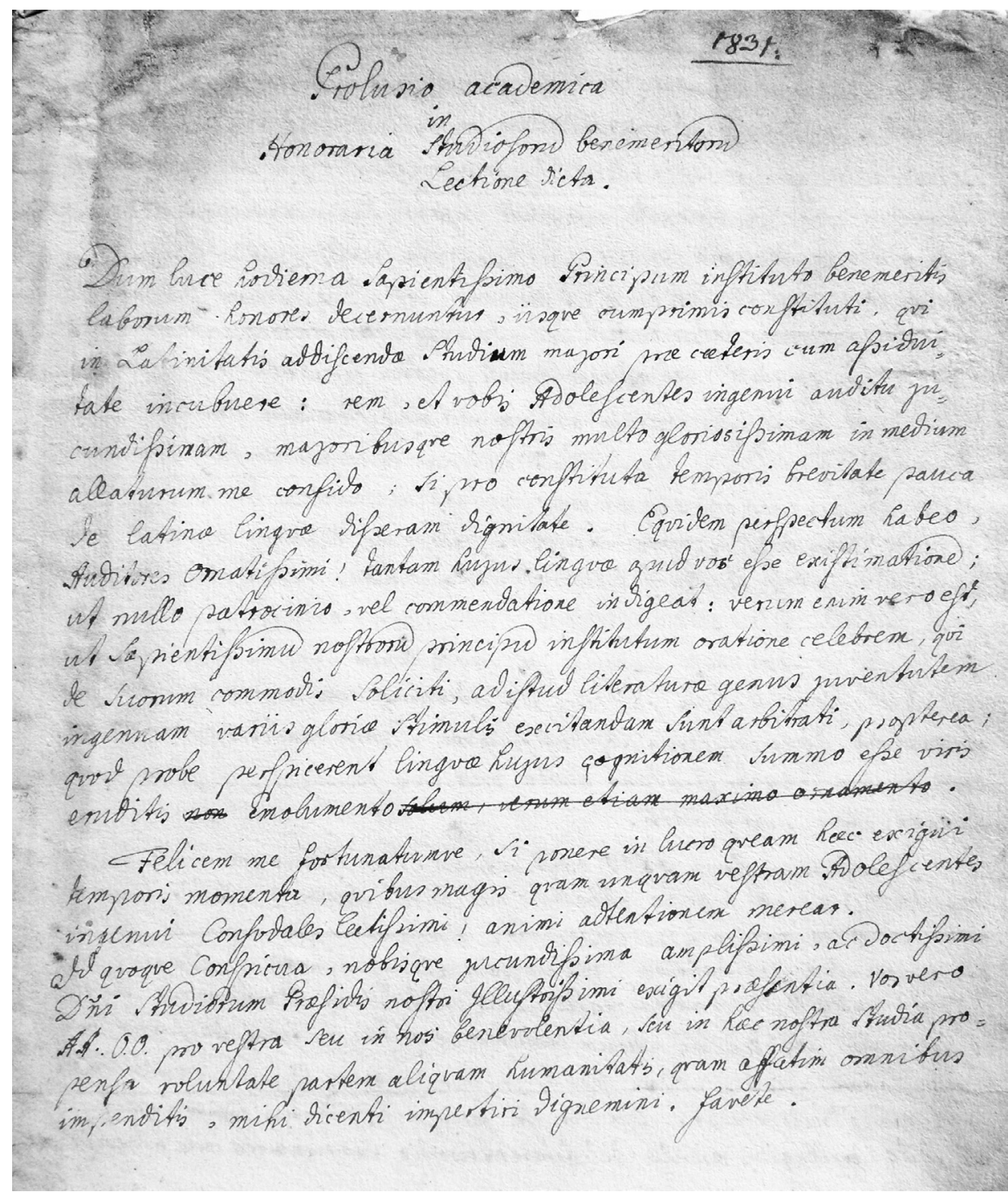

Slika 5: Prva stran spisa Prolusio academica, napisanega s Pöhmovo pisavo

(5) Na koncu pregleda glavnih virov za preučevanje življenja in dela p. Mavricija Pöhma, ki so v Sloveniji, velja omeniti še »Zgodovino frančiškanskega samostana in cerkve v Novem mestu« p. Alfonza Furlana, ki je v več delih izšla v Dolenjskih novicah leta 1919, torej več kot sto let po Pöhmovi smrti. Čeprav je to delo lahko le pomožni vir za preučevanje Pöhmovega življenja, so v njem tudi zanimivi zapisi o Pöhmu, ki po navedbah avtorja temeljijo na virih prve roke, kot je zdaj že izgubljeni Catalogus omnium provinc. S. Crucis defunctorum anno 1803. Po njem je p. Furlan povzel posmrtni opis p. M. Pöhma, ki več pove o njem kot človeku. Tu tako beremo, da je bil Pöhm ne samo »izvrsten organist in 
muzik» ter »marljiv prefekt in gvardijan«, pač pa tudi »priden spovednik« in »spreten« človek, »vsem ljub, moder in prijazen«. Zato je bil njegov pogreb na veliko nedeljo 1803 takšen, kakršnega »Novo mesto še ni videlo«. »Pokopan je poleg poti v sredi med [z] akristijo in cerkvenimi vrati poleg p. Kalista Weibla. ${ }^{22}$

O Pöhmu kot organistu govorijo zaznamki (»Org.« in »Organista«) ob njegovem imenu že iz časa, ko je bil študent teologije v Ljubljani. V tej vlogi ga omenja Protokol frančiškanskega samostana $v$ Ljubljani (1765-1785) že leta 1767, nato pa še vsako leto do njegovega odhoda iz Ljubljane. V seznamih tamkajšnjih redovnikov iz let 1769 in 1770 je Pöhm celo edini, ki je nedvoumno označen kot organist.

Omenjeno gradivo do leta 1782 označi tako Pöhma le še enkrat, in sicer v posebnem seznamu vseh frančiškanov v provinci Sv. Križa iz leta 1778 . V njem so poleg imen redovnikov navedene še njihove zadolžitve v samostanu, ta seznam pa je edini rokopis te vrste iz sedemdesetih let 18 . stoletja pri nas. ${ }^{23}$ Zato ni mogoče trditi, da Pöhm v tem času večinoma ni opravljal dela organista. Tudi oba prej omenjena ljubljanska protokola (tj. »samostanski« iz let 1765-1785 in provincialni iz let 1772-1784) po letu 1771 Pöhma ne omenjata več v zvezi z njegovim delom v samostanu, pač pa le še v krajših seznamih redovnikov s pomembnejšimi zadolžitvami v provinci, kot je bilo Pöhmovo poučevanje na gimnaziji v Novem mestu. Protokol novomeškega samostana, ki je glavni vir za poznavanje Pöhmovega dela v njem, pa vsebuje podatke le za leto 1782 in od leta 1784 naprej.

Da je Pöhm v tem samostanu opravljal dolžnosti organista tudi leta 1783, dokazuje prej omenjenemu seznamu iz leta 1778 podoben seznam redovnikov za leto 1783, ki je prav tako v Ljubljani. ${ }^{24} \mathrm{~V}$ Novem mestu hranjeno gradivo to Pöhmovo zadolžitev potrjuje še za leta od 1784 do 1786 (za leto 1787 ni podatka, seznam redovnikov v novomeškem samostanu iz leta 1788 pa pri nobenem od njih ne navaja zadolžitve organista) in za leta 1789, 1790, 1802 in 1803.

Še tretji seznam vseh redovnikov province Sv. Križa s podatki o njihovem delu je iz leta 1791 in je tudi v Ljubljani. ${ }^{25}$ Drugače kot pri imenih nekaterih drugih redovnikov v tem seznamu - npr. pri imenu Florencija Andreja (»Florentinus Andre «), ${ }^{26}$ ki je bil tako kot Pöhm tedaj v Novem mestu - pri Pöhmovem imenu ni zapisa o tem, da bi bil tega leta organist, pač pa je le zaznamek, da je gvardijan. To pomeni, da po letu 1790, ko je že

${ }^{22}$ Furlan, »Zgodovina frančiškanskega samostana in cerkve v Novem mestu«, Dolenjske novice, 14. avgust 1919.

${ }^{23}$ Catalogus | Omnium Patrum, et Fratrum | Provincice S. Crucis Croatice-|Carniolice. S. Ordinis Minorum |Strict. Obsrv: S. P. N. Francisci. | 1778. Spis je v ASFP.

${ }^{24}$ Catalogus | Patrum, et Fratrum Minorum | Strictioris Observantice Provin = | cice S: Crucis Croatice Carni $=\mid$ olice. Domino Famulantium $\mid$ 1783. Spis je v ASFP.

${ }^{25}$ Catalogus $\mid$ Patrum, ac Fratrum | Provincice S. Crucis Carniolice, Domino Servientium. | Anno 1791. Spis je v ASFP.

${ }^{26} \mathrm{~V}$ pregledanem gradivu v Novem mestu in Ljubljani so podatki, ki sporočajo, da je p. Florencij Andre (24. maja 1730 - 30. januarja 1807) kot organist deloval v Novem mestu že v letih 1759-1761, 1764, 1767 in 1769, v Ljubljani v letih 1774-1777 in 1778 ter v Brežicah v letih 1781 in 1783; nato je bil ponovno v Novem mestu do junija 1797, ko se je vrnil v Ljubljano, kjer je umrl. V frančiškanski red je vstopil s krstnim imenom Joannes oktobra 1750. 
tretje leto vodil samostan v Novem mestu, Pöhm verjetno res ni več opravljal dolžnosti organista. Tako je bilo še vse do leta 1802 oz. smrti Kalista Weibla (»Calistus Weibl«) marca 1801, ${ }^{27}$ ko je novomeški samostan ostal še brez drugega organista (Andre je Novo mesto zapustil junija 1797) in je Pöhm ponovno prevzel tudi organistove dolžnosti.

$* * *$

Na podlagi zapisov v dokumentih ljubljanskega in novomeškega arhiva ter že omenjenih izsledkov raziskave izvora in avtorstva muzikalij pri novomeških frančiškanih lahko sklepamo, da je bil M. Pöhm tesno povezan s Kalistom Weiblom. ${ }^{28}$ Med temi muzikalijami je namreč precej takšnih, ki sta jih napisala deloma Pöhm, deloma Weibl ${ }^{29}$ in so večinoma na papirju domačega (kranjskega) izvora in na papirju, uvoženem s sosednje Koroške in Štajerske, ki je, kot že rečeno, ob domačem takrat prevladoval pri nas. Med muzikalijami, napisanimi deloma s Pöhmovo, deloma z Weiblovo roko, deloma pa še z rokami drugih

${ }^{27}$ P. Kalist Weibl je bil rojen v Novem mestu 10. julija 1749. Po končani gimnaziji v rodnem kraju je s krstnim imenom Ignacij (»Ignatius«) 10. septembra 1767 vstopil v Nazarjah v noviciat in se leto zatem zaobljubil kot redovnik. Ti podatki so v Tyrocinium Seraphicum v ASFP (fol. 140: »Ignatius | Weibl Carn. Rudolphswertensis civis Rhetor nat. 1749 die 10. Juliÿ, cui nomen | impositum S. Calisti«). V drugih tu navedenih virih iz Ljubljane in Novega mesta so še zapisi, ki povejo, da je bil Weibl leta 1769 študent filozofije na Sveti gori in da je v letih 1771, 1772 in 1774 (za leto 1773 ni podatka) študiral teologijo pri frančiškanih v Ljubljani. Leta 1774 je bil v ljubljanskem samostanu tudi organist. Tu je orglal vsaj še leta 1780 in 1781. Seznam redovnikov iz leta 1778 (glej op. 23) pravi, da je bil Weibl tega leta organist v samostanu na Trsatu. V katerem samostanu je bil Weibl nastanjen leta 1782, v ljubljanskem ali novomeškem, ni jasno, saj ga ljubljanski Protokol z 19. avgusta 1782 omenja kot člana ljubljanske frančiškanske družine, medtem ko ga seznam redovnikov z istim datumom v novomeškem Protokolu navaja kot člana novomeške družine. Seznam redovnikov iz leta 1783 (glej op. 24) Weibla omenja med tedanjimi redovniki v Novem mestu, v seznamih za leto 1784 pa je Weibl spet omenjen dvakrat: kot redovnik v Novem mestu in tudi v Ljubljani. Že vsaj novembra 1784 je Weibl zagotovo poučeval $\mathrm{v}$ Novem mestu, $\mathrm{v}$ gimnaziji prvošolce in na normalki učence četrtega razreda. Tako še $\mathrm{v}$ letih 1785, 1786 (podatka za leto 1787 ni) in 1788; od leta 1789 do 1793 ter od leta 1795 do 1801 je poučeval drugi in tretji razred gimnazije (»Profess. Gram. et Synt.«). V več seznamih novomeških redovnikov tega časa je Weibl označen tudi kot organist. Oba takšna seznama iz leta 1794 (tj. seznam »Familia Conventus Neostad.« in seznam »Vestiarium Cntus. Neostad.« v Protokolu novomeškega samostana) pa Kalista Weibla ne navajata kot člana novomeške družine in tako potrjujeta navedbo Frana Ilešiča iz 1906, da je Weibl spomladi 1793 za nekaj časa odšel na Dunaj zaradi obtožb v zvezi s poneverbo spričevala enemu od dijakov v novomeški šoli (podrobneje o tem Ilešič, »Novomeški prošt Fran Nikola Peršil (1790-1797)«, 81). Kinderić tudi navaja, da je Weibl začel študirati teologijo že leta 1770 v Klanjcu na Hrvaškem (Kinderić, Franjevci uz orgulje, 106). Weibl je umrl 30. marca 1801 v Novem mestu. (Če ni navedeno drugače, so vsi ti podatki v pregledanem gradivu iz 18. in 19. stoletja v ASFP in FSANm.)

${ }^{28}$ Pöhm je z Weiblom prišel v stik zagotovo vsaj že leta 1771 v Ljubljani; pozneje (od leta 1784 do Weiblove smrti) sta skupaj prebivala v novomeškem samostanu in si vsaj v prvih letih svojega redovnega življenja v Novem mestu delila zadolžitve samostanskega organista, in sicer skupaj $\mathrm{z}$ vikarjem p. Florencijem Andrejem.

${ }^{29}$ Podrobneje o tem Škrjanc, »P. Mauritius Pöhm and his contribution to musical life in Novo mesto during the second half of the eighteenth century«, 240. 


\section{Hprilis.}

Carolostadii. S2. Pifzus Mersnit. Theolmoral.stud. an. Sel.4. itio.

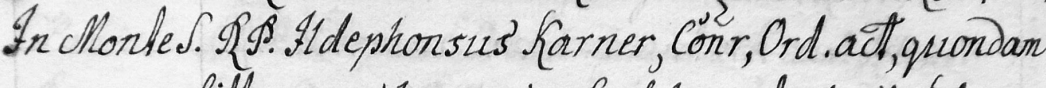
liflerarzm humanior. Projefsor. el.ph. Si. Alel. 33 . i 768.

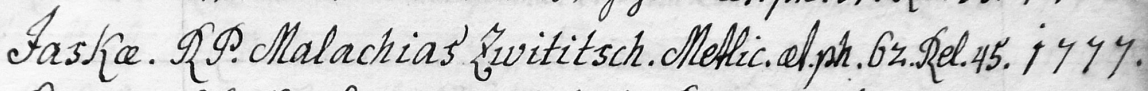
qunce. RP. Seo Suppantschitsch. Sarochice domestice Cooperafor act. al. phys. 46. Afel. z6.

Neostadü.At. A. Llauritius Fochm Bohemus, quondam Artium liberalium in Gymnasio nostro fro.

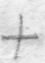

fepor, Organiota, et Alusicus prastantifoi." mus, in annum ifotum hujus. Oonventus Dianus, à prixdentia ceconomica, morum ouav. tate, chatitate, in Deum, et Foximum fulu."

Labair. mum commindatus: at.phyo. S8. Aetiene 40. is0?. M. R. . Angelinus Dernoufheh, act. Hoppit. Povisor, et farochiodomeflied coopeneri. a. nhys. 4\%. hel. 24.

Slika 6: Nekrolog p. Pöhmu iz leta 1803 (Necrologium provincice S. Crucis [...] Ab anno 1490)

kopistov, je nekaj tudi takšnih, ki so na papirju tujega izvora. Zanj lahko domnevamo, da k nam ni prišel nepopisan, temveč z že napisano notno vsebino.

Na takem papirju je prepis prvotiska kvartetov op. 1 I. Pleyela iz ok. leta 1782 (SINf, Ms. mus. 285). Tu ga velja posebej omeniti zato, ker vsebuje informacije, ki lahko pomembneje prispevajo k reševanju zgoraj omenjenih vprašanj: o poreklu »Pöhmovih muzikalij« s papirjem tujega izvora, o dveh še nepojasnjenih obdobjih v njegovem življenja po prihodu v Kamnik in o vlogi Pöhma kot »migranta« pri oblikovanju repertoarja v novomeškem samostanu v zadnji četrtini 18. stoletja. Ta rokopis namreč skoraj zagotovo ni nastal naenkrat in je delo več kopistov. Njegov verjetno najstarejši del - separat viole - je napisal neznani prepisovalec s pisavo, ki ni domača, in je na papirju z vodnim znakom $\mathrm{v}$ obliki črke W; ta papir je bil zelo pogost na Dunaju v zadnjih treh desetletjih 18. stoletja. Drugače kot na Kranjskem so dunajski trgovci papir tedaj pogosto uvažali iz severne Italije. Uvažali so tudi papir bratov Gava iz Benetk, ki ga označujejo inicialke GFA. Na njem so v Ms. mus. $285 \mathrm{z}$ Weiblovo pisavo napisani parti prve in druge violine ter basa. Da sta oba dela rokopisa zares narejena na papirju, aktualnem na Dunaju v zadnji tretjini 18. stoletja, potrjuje drugi novomeški rokopis, SI-Nf, Ms. mus. 98, ki je na enakem papirju in 
je skoraj zagotovo nastal $v$ eni od takrat številnih dunajskih prepisovalnic not $\mathrm{v}$ prvem ali drugem desetletju po letu 1775 (rokopis je namreč prepis prvotiska klavirskih koncertov op. 7 Johanna Christiana Bacha, natisnjenih v Londonu tega leta). Tretja in verjetno najmlajša plast rokopisa Ms. mus. 285 je še en, tokrat Pöhmov prepis obeh violinskih partov, ki je na domačem (Kumarjevem) papirju iz Ajdovščine in je torej najverjetneje nastal na naših tleh po predlogi, napisani z Weiblovo roko. Weibl je izdelal še naslovnico rokopisa, na katero je Pöhm pozneje dodal zaznamek o svoji lastni rabi not. ${ }^{30}$

Večji del rokopisa Ms. mus. 285 je torej lahko nastal na Dunaju, deloma pod roko Kalista Weibla, ki je tam prebival v času med spomladjo 1793 in jesenjo 1794, rokopis pa bi v novomeški samostan lahko prinesel ob svojem povratku vanj pred julijem 1795, ${ }^{31}$ in sicer skupaj z več drugimi muzikalijami, ki precej nedvoumno dopuščajo to možnost - kot npr. omenjeni prepis Bachovih koncertov op. 7 in zelo podoben prepis različnih klavirskih del avstrijskih skladateljev (J. A. Štěpán, Hengsberger, G. Chr. Wagenseil, A. C. Adlgasser idr. - SI-Nf, Ms. mus. 98; ta rokopis je tako kot rokopis Ms. mus. 285 pozneje prešel v Pöhmovo last). Pöhm, ki je devetdeseta leta 18. stoletja zagotovo preživel v Novem mestu, ${ }^{32}$ je Pleyelovim kvartetom dodal še lastnoročno napisan drugi izvod partov dveh violin, najbrž zaradi izvedbe s podvojenima violinskima glasovoma.

Čeprav je rokopis Ms. mus. 285 samo majhen del novomeške zapuščine not iz 18. stoletja, ki vsebuje več kot štirideset muzikalij s »sledmi« Pöhmove rabe, je na podlagi pravkar pojasnjene hipoteze vseeno mogoče sklepati, da Pöhm morda le ni bil tako odločilna oseba pri ustvarjanju novomeškega repertoarja ob koncu 18. stoletja, kot se je v preteklosti domnevalo - kot že rečeno, zaradi številnih zapisov njegovega imena na naslovnicah not $\mathrm{v}$ tem repertoarju in domneve, da je $\mathrm{v}$ naše kraje prišel $\mathrm{s}$ takrat glasbeno razvitejše Češke okoli leta 1774, ko je imel približno trideset let in že izdelane nazore. Oboje namreč spodbuja domnevo o Pöhmu kot posebno zaslužnem »prišleku s Češkega«, ki je v naše kraje zanesel številne note s tedaj sodobno glasbo srednjeevropskih skladateljev. Vendar ta domneva ni utemeljena. Med približno sto trideset muzikalijami v Novem mestu iz časa pred Pöhmovo smrtjo leta 1803 sta namreč le dve takšni, ki sta bili zagotovo v Pöhmovi rabi in sta verjetno res nastali na Češkem še pred Pöhmovim prihodom v kamniški noviciat. ${ }^{33}$ Večina preostalih not v njegovi zapuščini je mlajšega datuma in domačega izvora, le nekaj pa je takšnih, ki bi lahko v tistem času prispele $\mathrm{k}$ nam od drugod.

Kdo jih je prinesel sem, še ne vemo zagotovo. Da bi bil to Pöhm, je glede na pojasnjena dejstva in možna sklepanja na njihovi podlagi malo verjetno, kljub temu, da ni jasno, kje je prebil dve približno triletni obdobji po svojem prihodu v Kamnik. Tudi druge muzikalije s pripisi Pöhmovega lastništva, ki imajo tuji papir in bi jih Pöhm, če je omenjeni obdobji preživel na tujem, lahko prinesel iz tujine, vsebujejo namreč kazalce,

${ }^{30}$ Ibid., $243-244$ in 252.

${ }^{31}$ Gl. op. 27.

${ }^{32}$ To dokazujejo omenjena Decreta iz let med 1788 in 1803. Gl. op. 21.

${ }^{33}$ To sta rokopisa SI-Nf, Ms. mus. 416 in 134. Prvi vsebuje fragmente slavnostne maše v C-duru Františka Xaverja Brixija, drugi pa mašo v C-duru neznanega avtorja. Več o tem Škrjanc, »P. Mauritius Pöhm and his contribution to musical life in Novo mesto during the second half of the eighteenth century«, 243 in 250. 
da so v njegovo last prešle šele v času, ko je že živel v Novem mestu. Takšne muzikalije so npr. naslednje: rokopis SI-Nf, Ms. mus. 116b, katerega papir izhaja z Zgornje Štajerske in ga je napisala neznana roka, v Pöhmovo last pa je prišel leta $1779 ;{ }^{34}$ rokopis SI-Nf, Ms. mus. 54b, ki je prav tako napisan s pisavo neznanega avtorja na še neidentificiranem papirju, vendar zagotovo ne domačem, in ga je Pöhm kot svojo last označil leta $1780 ;{ }^{35}$ ter rokopis SI-Nf, Ms. mus. 131, ki je že izvirno datiran z letnico 1790 in vsebuje deloma papir istega izdelovalca kot rokopis $116 \mathrm{~b}$, deloma pa papir z Moravske. ${ }^{36}$

Vloga p. M. Pöhma pri nastanku novomeškega repertoarja se torej kaže predvsem kot vloga zbiratelja not s takrat razmeroma sodobno glasbo na naših tleh. Temu mnenju pritrjuje še ena obsežnejša skupina rokopisov v novomeškem samostanu z glasbo čeških, avstrijskih in italijanskih skladateljev s sredine 18. stoletja in njegove druge polovice. Gre za precej enovito skupino muzikalij, napisanih pretežno na papirju, ki je, kot že rečeno, med šestdesetimi in devetdesetimi leti 18. stoletja prevladoval na Kranjskem. Te note so torej skoraj zagotovo nastale pri nas, vse pod roko še neznanega kopista z imenom Andreas Pitter, ki je bil tudi njihov prvi lastnik. V Pöhmovo last so prešle šele kasneje, kar dokazujejo zaznamki z njegovim imenom na naslovnicah, ki jih je Pöhm zapisal čez Pittrovo ime. ${ }^{37}$

Z vsem tem dobiva tudi pojem »glasbene migracije« pri spoznavanju Pöhmovega prispevka k zgodovini glasbe na Slovenskem drug pomen. Bliža se pomenu, ki ga ima prehajanje novih glasbenih idej iz enega v drugo okolje na sploh, oziroma uveljavljanju novih idej v domačem okolju z vnašanjem sodobne glasbe od drugod. Ob tem se izgublja osebno naglašeni pomen p. M. Pöhma kot posebno odločilnega dejavnika v tem dogajanju. Upoštevajoč nova spoznanja o njegovem življenju in delu je Pöhma z vidika tega pojma pravzaprav težko razlikovati od dveh njegovih približno desetletje starejših kolegov, p. Bena Majerja in Jakoba Frančiška Zupana, ki sta s svojimi nazori in izkušnjami morda celo usodneje zaznamovala Pöhmov glasbeni razvoj že v času njegove preskušnje v kamniškem noviciatu kot pa dejstvo, da je bil po narodnosti Čeh. Niti pri Majerju (po rodu Tirolcu, ki je še kot najstnik obiskoval gimnazijo v Novem mestu in nato tako kot Pöhm skrbel za glasbo v več samostanih province Sv. Križa) ${ }^{38}$ niti pri Zupanu (»prišleku« z Zgornje Štajerske, ki je prispel v Kamnik s približno dvajsetimi leti, v njem preživel večino svojega

${ }^{34}$ Rokopis vsebuje Salve Regina Chr. Gödla za štiri pevske glasove in t. i. cerkveni trio, zaznamek, napisan s Pöhmovo pisavo, pa se glasi: »P. Mauritii OMR | 779«.

${ }^{35}$ Rokopis vsebuje štiriglasno uglasbitev lavretanskih litanij A. Ivančiča s spremljavo dveh violin, para klarinov in orgel; zaznamek, napisan s Pöhmovo pisavo, se glasi: »Ex [...]: C P[...] $780 \mid$ P. Mauritii OMR«.

${ }^{36}$ Rokopis vsebuje Fischerjevo mašo Missa S. Joannis Nepomuceni M. za štiri pevske glasove in orkester. Podrobneje o rokopisih SI-Nf, Ms. mus. 116b, 54b in 131 gl. Škrjanc, »P. Mauritius Pöhm and his contribution to musical life in Novo mesto during the second half of the eighteenth century«, 242-244 in 251.

${ }^{37}$ Gre za rokopise SI-Nf, Ms. mus. 113b, 119, 127, 280, 283a, 283b, 284, 289a in 289b, ki vsebujejo glasbo naslednjih skladateljev: Ignaz Umlauf, Johann Baptist Vanhal, Jiří Ignác Linek, Giuseppe de Razelsperg, Pietro Domenico Paradisi, Niccolò Piccini in Carl Stamitz. Podrobneje o tem gl. Škrjanc, »P. Mauritius Pöhm and his contribution to musical life in Novo mesto during the second half of the eighteenth century«, 240.

${ }^{38}$ Gl. op. 14. 
življenja in postal vodilni glasbenik tistega časa pri nas) ni bilo to, da sta prišla k nam od drugod, nikoli razumljeno kot posebno odločilno za vsebino njunega glasbenega dela.

$\mathrm{Na}$ Pöhmovo glasbeno delo in okus, ki mu je narekoval izbiro not za »lastno rabo« morda že v ljubljanskem, zagotovo pa kasneje v novomeškem samostanu, so lahko različno vplivali še drugi kolegi organisti, s katerimi je sodeloval v obeh ustanovah. Poleg Kalista Weibla so bili to še patri Elias Schintlholzer, Maximus Selderer, Januarius Nessing, Marcelianus Vodnigk ter že omenjena patra Liborij Glögler in Florencij Andre. Slednji je bil organist v novomeškem samostanu vsaj že leta 1759 in nato s prekinitvami še v šestdesetih, osemdesetih in devetdesetih letih 18. stoletja, ${ }^{39}$ kar pomeni v času, ko je tu nastajal repertoar z glasbo srednjeevropskih zgodnjeklasicističnih skladateljev in je v samostanu prebival tudi Pöhm.

Zanimivo je, da so po Pöhmovem odhodu iz Ljubljane njegovo mesto v samostanu zasedli kar trije novi organisti: ${ }^{40}$ p. Zachaenas Rape (»Zachaenas Rappe«), p. Kalist Weibl in p. Robert Lesjak (»Robertus Lessiagk«). ${ }^{41}$ Ljubljanski protokol iz let 1765-1785 navaja Lesjaka še kot vodjo samostanske glasbene kapele (»Chori Magr. Org.«), in sicer v zapisih, nastalih po njegovi vrnitvi iz Kamnika v Ljubljano leta 1780. To morda pomeni, da so ljubljanski frančiškani tedaj razširili delovanje svojega kora in pri bogoslužju izvajali zahtevnejšo cerkveno glasbo. Notno gradivo iz tega obdobja, ki je v njihovem sedanjem, tj. nekdanjem avguštinskem samostanu in bi lahko izviralo iz »starega« frančiškanskega samostana na današnjem Vodnikovem trgu v Ljubljani, je ohranjeno le v fragmentih,

${ }^{39}$ Gl. op. 26.

${ }^{40}$ Četrti organist v ljubljanskem samostanu leta 1771 je bil Glögler, ki je dolžnosti organista ob Pöhmu opravljal tudi pozneje v Novem mestu (po letu 1784). Glej op. 18. Gradivo v frančiškanskih samostanih v Novem mestu in Ljubljani razkriva razmeroma veliko število organistov, ki so v drugi polovici 18. stoletja delovali v samostanih province Sv. Križa. Poleg že omenjenih v tem prispevku so bili to še: p. Leopoldus Au, p. Julius Christan, p. Burchardus Cramer, p. Ruffinus Czochar, p. Nicephorus Farhinetti, p. Delphinus Feuerpach, p. Aloysius Fridhelm, p. Pergentius Gabritsch, p. Casimir Gallich, p. Cajetanus Ingolich, p. Lazarus Jambschig, p. Cajetanus Jagolitsch, p. Quirin Jucha, p. Placidus Juray, p. Jeremias Jurmann, p. Angelicus Kaydasch, p. Longinus Keilling, p. Fortunatus Kuntara, p. Querinus Kuntara, p. Franciscus Lach, p. Liberatus Lander, p. Carpophorus Lassperger, p. Seraphion Leichtenegger, p. Cecilianus Loqueil, p. Valerianus Luschang, p. Gelasius Malkovich, p. Leonardus Mogorich, p. Arnoldus Muhina, p. Valerianus Omerza, p. Christinus Pacher, p. Procopius Pergmann, p. Hortulanus Plazer, p. Bernardus Pochlin, p. Marinus Podlipneg, p. Andreas Podlipnigg, p. Donatianus Rebhann, p. Victorinus Reütter, p. Philemon Sauritsch, p. Bruno Staravanig, p. Romualdus Strukl, p. Franciscus Tscholk, p. Donaus Valeti, p. Haycinthus Zhebulz, p. Emericus Zorn in p. Clarus Witniz.

${ }^{41}$ Iz podatkov v pregledanem gradivu v Novem mestu in Ljubljani je razvidno, da je bil p. Robert Lesjak rojen 30. oktobra 1737 in krščen z imenom Karel (»Carolus«). V frančiškanski red je vstopil oktobra 1757 v Kamniku. Leta 1764 je bil član ljubljanske družine frančiškanov, od leta 1776 naprej pa je dobra štiri leta nadomeščal Bena Majerja v Kamniku kot vikar in samostanski organist. Leta 1778 je tu tudi poučeval mlade laike v petju in glasbi. V letih od 1781 do 1784 je bil kapelnik in organist v ljubljanskem frančiškanskem samostanu, po tem datumu pa se sled za Lesjakom v omenjenem gradivu izgubi. Najbrž je v tem času zapustil frančiškanski red, saj ga nekrologi redovnikov province Sv. Križa ne omenjajo. Podrobneje o Lesjakovem življenju in delu gl. tudi Kinderić, Franjevci uz orgulje, 152-157. 
zato takšnega ugibanja ne more niti potrditi niti ovreči. Povsem drugače je z gradivom v novomeškem samostanu, ki s svojim obsegom in sestavom spodbuja domnevo, da je v tej ustanovi nekoč deloval precej obsežen in razmeroma kakovosten glasbeni ansambel, pa čeprav drugi viri o njem zaenkrat še molčijo.

O sestavi repertoarja v ljubljanskem samostanu v času, ko je glasbo v njem vodil p. Lesjak, lahko posredno sklepamo iz vsebine njegovih skladb, ohranjenih v hrvaškem Klanjcu. ${ }^{42}$ Te izražajo na splošno zelo podobno slogovno usmeritev kot osredji del repertoarja iz »Pöhmovega obdobja« v Novem mestu. Enako velja za vsaj še dva bolje ohranjena repertoarja iz tega obdobja pri nas: za repertoar ljubljanske stolnice in celjske opatijske cerkve. Zato lahko s precejšnjo gotovostjo trdimo, da je bila slogovna smer srednjeevropskih zgodnjih klasicistov takrat že prevladujoča tudi v glasbi po cerkvah na Slovenskem. Zbiranje not $\mathrm{s}$ takšno vsebino v eni od njih v tem času potemtakem ni bilo več izjemno, temveč je le sledilo glavnemu toku umetnostnega dogajanja pri nas.

Odgovor na vprašanje v naslovu te razprave, ali je bil p. M. Pöhm glasbeni migrant, torej ne more biti enoznačen. Odvisen je od tega, kateri pomen besedne zveze »glasbena migracija« naglasimo. Če jo razumemo le kot oznako za vsak »stvarni premik« nekega glasbenika, učbenika, not ipd. iz enega v drugi geografski prostor, potem je bil Pöhm najbrž vsaj enkrat v življenju res pravi glasbeni migrant - ob svojem prihodu v kamniški noviciat leta 1763, če je s Češkega vanj prišel kot že relativno dobro podučen glasbenik. V tem pogledu sta bili tudi obe Pöhmovi morebitni bivanji v tujini med leti 1764 in 1767 ter 1771 in 1774 (za katera v resnici še ne vemo, kje jih je prebil) »glasbeni migraciji« - kot migraciji glasbenika, ki sta vplivali na njegovo nadaljnje delo. Ko pa iščemo odgovor na nekatera pomembnejša vprašanja v (domači) zgodovini glasbe, kot je vprašanje o razlogih za »prav takšno in ne drugačno« sestavo ohranjenega glasbenega repertoarja v Novem mestu iz časa, ko je tu deloval p. Pöhm, postane pojem glasbene migracije v zvezi z njim vsebinsko skromen. Omejuje se le na dve muzikaliji v novomeškem samostanu, ki bi ju Pöhm lahko prinesel s Češkega, in seveda na njegov splošni prispevek pri prevzemanju sodobne tuje glasbe pri nas.

\section{Literatura}

Furlan, Alfonz. »Zgodovina frančiškanskega samostana in cerkve v Novem mestu.« Dolenjske novice 35, št. 1-30 (1919).

Höfler, Janez. »Glasbenozgodovinske najdbe XVIII. in XIX. stoletja v Novem mestu«. Kronika 15, št. 3 (1967): 135-148.

---. Tokovi glasbene kulture na Slovenskem od začetkov do 19. stoletja. Ljubljana: Mladinska knjiga, 1970.

Ilešič, Fran. »Novomeški prošt Fran Nikola Peršil (1790-1797). (Slika iz jožefinske dobe ljubljanskega nadškofa Mihaela barona Brigida)«. Izvestja Muzejskega društva za Kranjsko 16, št. 3-4 (1906): 71-112.

${ }^{42}$ Gre za njegovi orgelski skladbi v rokopisu HR-KLf C-94 (RISM 500078075 in 500078076$)$. 
Kinderić, Petar Antun. Franjevaci uz orgulje. Krapina: Hrvatsko društvo crkvenih glazbenika, 2006.

Škrjanc, Radovan. »P. Mauritius Pöhm and his contribution to musical life in Novo mesto during the second half of the eighteenth century«. De musica disserenda 11, št. 1-2 (2015): 229-263.

Vrhovec, Ivan. Zgodovina Novega mesta. Ljubljana: Matica slovenska, 1891.

\author{
P. MAURITIUS PÖHM - A MUSICAL MIGRANT? \\ A CONTRIBUTION TO THE LIFE AND WORK OF A FRANCISCAN FRIAR IN \\ SLOVENIA IN THE SECOND HALF OF THE EIGHTEENTH CENTURY
}

\begin{abstract}
Summary
The Franciscan monastery in Novo Mesto (Germ. Rudolphswerth) holds a collection of music manuscripts that was owned by P. Mauritius Pöhm (1745-1803) and includes works by stylistically modern central European composers of the second half of the eighteenth century. In the past it was believed that Pöhm, a Bohemian by birth, had brought the collection from Bohemia. Yet an investigation of his life and examination of the watermarks found in the collection's paper reveal that this was not the case.

Pöhm entered the Franciscan monastery in Kamnik (Germ. Stein) when he was nineteen. He came from Pavlovice, a place that cannot be precisely identified because there are several towns bearing that name in Bohemia. He remained in Carniola (the central part of modern Slovenia) until the end of his life. There are only two periods in his biography (1764-1767, 1771-1774) for which no archival documents concerning his whereabouts have been found so far. In 1774 at the latest he settled in Novo mesto, where he remained until the end of his life, serving as organist, teacher at the lyceum, and guardian of the community. Pöhm's music collection was copied by several copyists, including himself. The brands of paper they used were for the most part, although not exclusively, available in Carniola and can be identified in other written records of the time. The music of Pöhm's collection was therefore not imported from abroad as has been assumed, but must have been copied in Carniola and other neighbouring Austrian regions.
\end{abstract}

